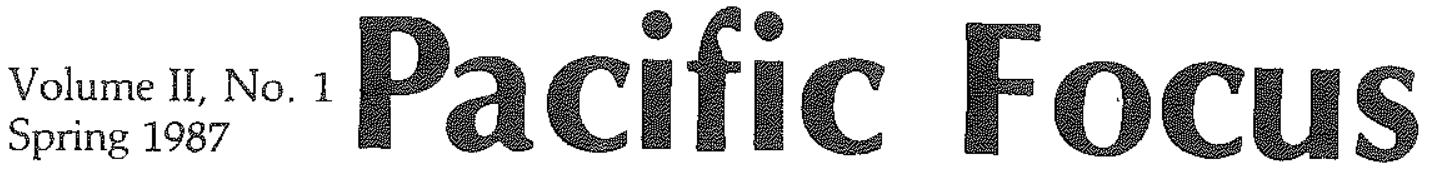 Inha Journal of International Studies
}

Determinants of Development Strategies in Latin America and East Asia

Comparative Performances of East Asian and Latin American NICs

Cross Regional Security Collaboration in Asia: A Balance Sheet

International Business and Political Risk in the Pacific Basin

Trade Frictions and Industrial Adjustment: The Textiles and Apparel Industry in the Pacific Basin

Security, Sovereignty and Economics: Armaments Limitation in Asia
Gary Gereffi

and Donald Wyman

Steve Chan

Sheldon W. Simon

Martin H. Sours

Chung-in Moon with Chull Ho Chang

David Winterford 


\section{Determinants of Development Strategies in Latin America and East Asia}

Gary Gereffi and Donald Wyman

\section{Introduction}

In recent decades a relatively small set of developing nations, commonly known as the newly industrializing countries (or NICs), has distinguished itself in a variety of ways. While observers differ somewhat in their definition and identification of the NICs, they agree that these countries have achieved rapid rates of economic growth, relatively high levels of industrialization accompanied by significant increases in per capita income, ${ }^{1}$ and prominence as exporters of manufactured products. For purposes of this paper the term NICs shall refer to the eight largest developing country exporters of manufactured goods, which means Argentina, Brazil, and Mexico in Latin America, Hong Kong, Singapore, South Korea, and Taiwan in East Asia, and India in South Asia. ${ }^{2}$ These countries also are among Third

The authors wish to acknowledge the helpful comments related to this paper made by participants at the conference on "Development Strategies in Latin America and East Asia: A Cross-regioral Comparison," Center for U.S.-Mexican Studies, University of California, San Diego, and Institute of the Americas, La Jolla, California, May 4-6, 1986. The conference papers will be published in Gary Gereffi and Donald Wyman (eds.), Development Strategies in Latin America and East Asia: New Perspectives on Contemporary Patterns of Industrialization, forthcoming.

1. One well-known World Bank economist has defined the NICs as those countries that had per capita incomes between $\$ 1100$ and $\$ 3500$ in 1978 , and in which the manufacturing sector accounted for at least 20 percent of gross domestic product in 1977. By these standards, eighteen countries qualified for NIC status. Bela Balassa, The Newly Industrializing Countries in the World Economy (New York: Pergamon Press, 1981), p. x.

2. See Colin I. Bradford, Jr., "The Rise of the NICs as Exporters on a Global Scale," in Louis Turner and Neil McMullen (eds.), The Newly Industrializing Countries: Trade and Adjustment (London: George Allen \& Unwin, 1982), p. 10 and Table 2.1.

Pacific Focus, Vol. II, No. 1 (Spring 1987), 5-33.

(C) 1987 by the Center for International Studies, Inha University. 
World leaders in their levels of industrial output, and they are comparable to the advanced industrial nations in the manufacturing sector's share of gross domestic product. ${ }^{3}$

The NICs have followed different paths in becoming industrialized. The two basic approaches are export-oriented industrialization (EOI), initiated by Japan and later adopted by the East Asian countries of Hong Kong. Singapore, South Korea, and Taiwan, and import-substituting industrialization (ISI), typified by the Latin American countries of Argentina, Brazil, and Mexico. ${ }^{4}$ One of the most interesting features of these NICs is that the choice, timing, and sequence of their development patterns have varied by region. ${ }^{5}$

During the 1930's the large Latin American countries were the first in the developing world to experience a significant increase in the breadth and depth of their industrial activities, and they did so on the basis of supplying their sizable internal markets with locally produced goods. By contrast, the NICs of East Asia industrialized later and in a more selective and outward-oriented fashion. Between 1955 and 1974, Hong Kong, Singapore. South Korea, and Taiwan all sustained growth rates of over 7 percent per year in gross domestic product, a record which was superior to the 4.7 percent average experienced by the industrialized economies. ${ }^{6}$ During the $1970^{\prime}$ s, the East Asian NICs not only

3. World Bank, World Development Report, 1986 (New York: Oxford University Press, 1986), Annex, Table 3, pp. 184-185.

4. Bela Balassa, "The Process of Industrial Development and Alternative Development Strategies," in his The Newly Industrializing Countries in the World Economy, pp. 1-26. India also has followed an import-substituting path of industrialization, but with much less reliance on direct foreign investment, foreign loans, or external trade than the other NICs. For an excellent review of this important case, see Aditya Mukherjee and Mridula Mukherjee, "The Political Economy of Indian Development: A Historical Perspective," in Gary Gereffi (ed.), The Origins and Consequences of National Development Strategies: Latin American and Asia Compared, forthcoming.

5. Gustav Ranis, "Challenges and Opportunities Posed by Asia's Superexporters: Implications for Manufactured Exports from Latin America," in Werner Baer and Malcolm Gillis (eds.), Export Diversification and the New Protectionism: The Experiences of Latin America (Champaign: University of IIlinois, 1981), p. 205.

6. The star economic performer in the postwar years is Japan, whose economy grew at the rate of 9.5 percent per annum between 1955 and 1974 . Edward K. Y. Chen, Hyper-growth in Asian Economies: A Comparative Study of 
grew far more rapidly than their Latin American counterparts, but they also had a more equitable distribution of income. ${ }^{j}$ Furthermore, the East Asian NICs appear to have adjusted much more successfully than the Latin American ones to the global economic crisis that originated in the $1970^{\prime} \mathrm{s} .{ }^{8}$

East Asia's superior economic performance during recent years has given renewed impetus to a debate about appropriate development policies in both governmental and academic circles. Officials in key multilateral institutions (e.g., the World Bank), in the United States government (e.g., the Agency for International Development), and in the internationalized segments of the private sector (e.g., in leading commercial banks) have advocated export-promoting policies as the new development orthodoxy for Third World nations, thus denigrating the import-substituting approach to industrialization. ${ }^{9}$ This interpre-

Hong Kong, Japan, Korea, Singapore and Taiwan (London: The Macmillan Press, 1979), pp. 9-10.

7. The distribution of income in the East Asian NICs is treated in Shirley W. Y. Kuo, Gustav Ranis, and John C. Fei, The Taiwan Success Story: Rapid Crowth with Improved Distribution in the Republic of China (Boulder, Co.: Westview Press, 1981), pp. 38-60 and Gustav Ranis, "Equity with Growth in Taiwan: How 'Special' is the 'Special Case'?," World Development 6:3 (1978), pp. 397-409. An argument that income inequality is on the rise in South Korea may be found in Hagen Koo, "The Political Economy of Income Distribution in South Korea: The Impact of the State's Industrialization Policies," World Development 12:10 (1984), pp. 1029-1037. On Latin America see Joel Bergsman, "Income Distribution and Poverty in Mexico," World Bank Staff Working Paper 395 (Washington, D.C.: World Bank, June, 1980); David Denslow, Jr. and William Tyler, "Perspectives on Poverty and Income Distribution in Brazil," unpublished manuscript, 1983; David Felix, "Income Distribution and the Quality of Life in Latin America: Patterns, Trends, and Policy Implications," Latin American Research Review 18:2 (1983), pp. 3-34.

8. This success has not gone unnoticed in the press. See, for example, Robert Gibson, "Asia's Little Dragons Spew Economic Fire," Los Angeles Times, July $15,1984$.

9. This view is typified by the March, 1984 issue of the influential report, World Financial Markets, issued by the Morgan Guaranty Trust Company. Focusing on whether Korea provides an appropriate adjustment model for the 1980 's, the report found that Korea's economic achievements "exemplify the benefits that can flow from an outward-looking, market-oriented strategy for economic adjustment and development...," p. 1. See also the discussion of the contrast between the successes of export promotion and the problems associated with import substitution in World Economic Outlook (Washington, D.C.: International Monetary Fund, 1985), pp. 182-183. 
tation has been challenged by scholars as well as by those associated with other multilateral institutions (e.g., the United $\mathrm{Na}$ tions, Economic Commission on Latin America and the U.N. Committee on Trade and Development). ${ }^{10}$ In addition, the debate surrounding EOI and ISI has generated substantial disagreement among a variety of political and economic actors in developing countries themselves.

A close examination of the evolution of development patterns in the two regions, however shows that historically the opposition between ISI and EOI poses a false dilemma. The two approaches have been compatable and even mutually reinforcing, as we will see below. We call attention, through, to the fallacy of attempting to replicate the East Asian model in substantially different circumstances.

The regional contrast in the development experience of the Latin American and East Asian NICs also raises major theoretical issues in the field of international political economy. One of these is the relative importance of internal and external determinants of national economic policies. Our contribution here lies in demonstrating that at similar choice points in their development experience (e.g., at the end of the initial stage of ISI), each regional group of NICs confronted a distinctive set of opportunities and constraints at both the international and domestic levels, which led to contrasting development sequences. Another issue is the interplay between various forms of linkage with the international system, and the types of social coalitions and state policies that are associated with each phase of development in the two regions. The way in which a country associates with the world economy may be both a cause and a consequence of the distribution of power and the structure of interests among the politically relevant actors in that society. The cross-regional analysis will help us explore this interplay.

The comparison of Latin American and East Asian NICs is particularly apt in addressing a central controversy in the dependency literature. This perspective, most commonly ap-

10. For an academic economist's challenge to EOI as the new orthodoxy see Colin I. Bradford, Jr., "The NICs: Confronting U.S. 'Autonomy"," in Richard E. Feinberg and Valeriana Kallab (eds.), Adjustment Crisis in the Third World (New Brunswick, N.J.: Overseas Development Council, 1984), pp. 121-129. 
plied to Latin American nations, has argued that extensive reliance on direct foreign investment, foreign loans, foreign aid, and exports of primary commodities produces growing inequality (internationally and domestically), inadequate economic integration in the local economy, authoritarian political regimes, social marginality, and slow or erratic rates of economic growth. ${ }^{11}$ The assumptions of the dependency literature are challenged by the experience of the East Asian NICs, which during the past two decades have industrialized rapidly, with relatively equitable distributions of income, and without extensive reliance on multinational corporations. ${ }^{12}$

In our view, a fundamental problem of the dependency approach for comparative purposes is that it has focused too heavily on the specific forms of dependence associated with Latin America's relationship to the world economy and on the hegemonic influence of the United States. The East Asian countries are particularly useful in showing that external linkages may be opportunities and not just constraints for developing countries. The cross-regional analysis of Latin America and East Asia enables us to better identify the conditions under which specific situations of dependency have positive, negative, or mixed consequences for national development.

The objectives of this paper are twofold. The first is to trace the contrasting patterns of development followed by the Latin

11. The literature that falls into what is now referred to as the dependency tradition is extensive. A classic statement is Fernando Henrique Cardoso and Enzo Faletto, Dependencia y desarrollo en América Latina (Mexico City: Siglo Veintiuno Editores, S. A., 1969), expanded and revised as Dependency and Development in Latin America (Berkeley: University of California Press, 1979). The dependency perspective is reviewed and analyzed in Gary Gereffi, The Pharmaceutical Industry and Dependency in the Third World (Princeton: Princeton University Press, 1983), Chapter 1.

12. This challenge is explored explscitly in Alice H. Amsden, "Taiwan's Economic History: A Case of Etàtisme and a Challenge to Dependency Theory," Modern China 5:3 (July, 1979), pp. 341-380 and Richard E. Barrett and Martin K. Whyte, "Dependency Theory and Taiwan: Analysis of a Deviant Case," American Journal of Socioloy 87:5 (1982), pp. 1064-1089. Hill Gates argues that the costs of dependency are merely disguised in Taiwan's case. See "Dependency and the Part-time Proletariat in Taiwan," Modern China 5:3 (July, 1979), pp. 381-408. 
American and East Asian NICs. We believe that the comparison will be sharpest if we examine a pair of NICs from each region: Brazil and Mexico from Latin America, and South Korea and Taiwan from East Asia. ${ }^{13}$

Secondly, we wish to identify and analyze the determinants of these development sequences. We will compare the two regions in terms of the following key determinants: natural resource endowments and internal market size, geopolitical factors, transnational economic linkages, state structures, elite policy preferences, prevailing development ideologies, and social coalitions. ${ }^{14}$ These determinants, we argue, help explain both similarities and differences in the development sequences that characterize the Latin American and East Asian NICs. Using this approach, we also will explore the interplay between external and internal determinants, and the relationship between forms of participation in the international economy and domestic political factors.

\section{Development Patterns and Strategies as Comparative Concepts}

The development experience of the Latin American and East Asian NICs is complex. One way to conceptualize their trajectories is in terms of development patterns that are historically and structurally situated. These development patterns have at least two dimensions: (1) the types of industries that are most prominent in each phase of a country's economic development;

13. The three other countries from these regions that are commonly referred to as NICs-Argentina, Hong Kong, and Singapore-share many aspects of this regional contrast in development sequences, but they also present distinctive features that cannot be treated in this paper.

14. The distinctive cultural heritages of Latin America and East Asia, although a fascinating and complex topic, do not seem to be primary determinants of the development patterns we are concerned with in this paper. The cultural traditions of each region have existed for centuries, while the development shifts we focus on are of relatively recent origin. Nonetheless, cultural influences do have an indirect effect on development policies, mediated through some of the variable we have identified (e.g., social coalitions, elite preferences, and development ideologies). 
and (2) the degree to which these leading industries are inwardly or outwardly oriented (i.e., whether production is destined for the domestic market or for export).

Based on a broad historical view of the development experience of Mexico, Brazil, South Korea, and Taiwan, we can distinguish four basic development patterns. Two of these are inward looking: horizontal ISI and vertical ISI. The other two are outward looking: a primary product export model and exportoriented industrialization. ${ }^{15}$ The basis for establishing two variants within the outward and inward approaches is the kind of product involved. In the primary product export model, the typical products are raw materials; in export-oriented industrialization, the products are manufactured goods. In horizontal import substitution, the objective is to produce locally some of the consumer goods that are being imported, and in almost all countries the key industries during this phase are textiles, apparel, and food processing. Vertical import substitution involves the substitution of consumer durables (e.g., automobiles), intermediate goods (e.g., petrochemicals and steel), and capital goods (e.g., heavy machinery). The timing and specific industries associated with each of these development patterns for the Latin American and East Asian NICs are detailed in Chart 1.

Development strategies, on the other hand, can be defined as sets of policies that shape a country's relationship to the global economy and that affect the domestic allocation of resources among industries. The notion of development strategies links sets of policies and particular structures of production in such a way as to shed light on a country's relationship to international markets and resources, and on its decisions about domestic economic growth and equity. A variety of policies may be used to establish a particular pattern of inward- or outward-oriented production, but our focus is on the broad strategy itself rather

15. In terms of economic policies, the inward- and outward-oriented aproaches are differentiated from each other by the presence or absence of an anti-export bias. Anne Krueger, "Export-Led Industrial Growth Reconsidered," in Wontack Hong and Lawrence B. Krause (eds.), Trade and Growth of the Advanced Developing Countries in the Pacific Basin (Seoul: Korea Development Institute, 1981), pp. 8-10. 


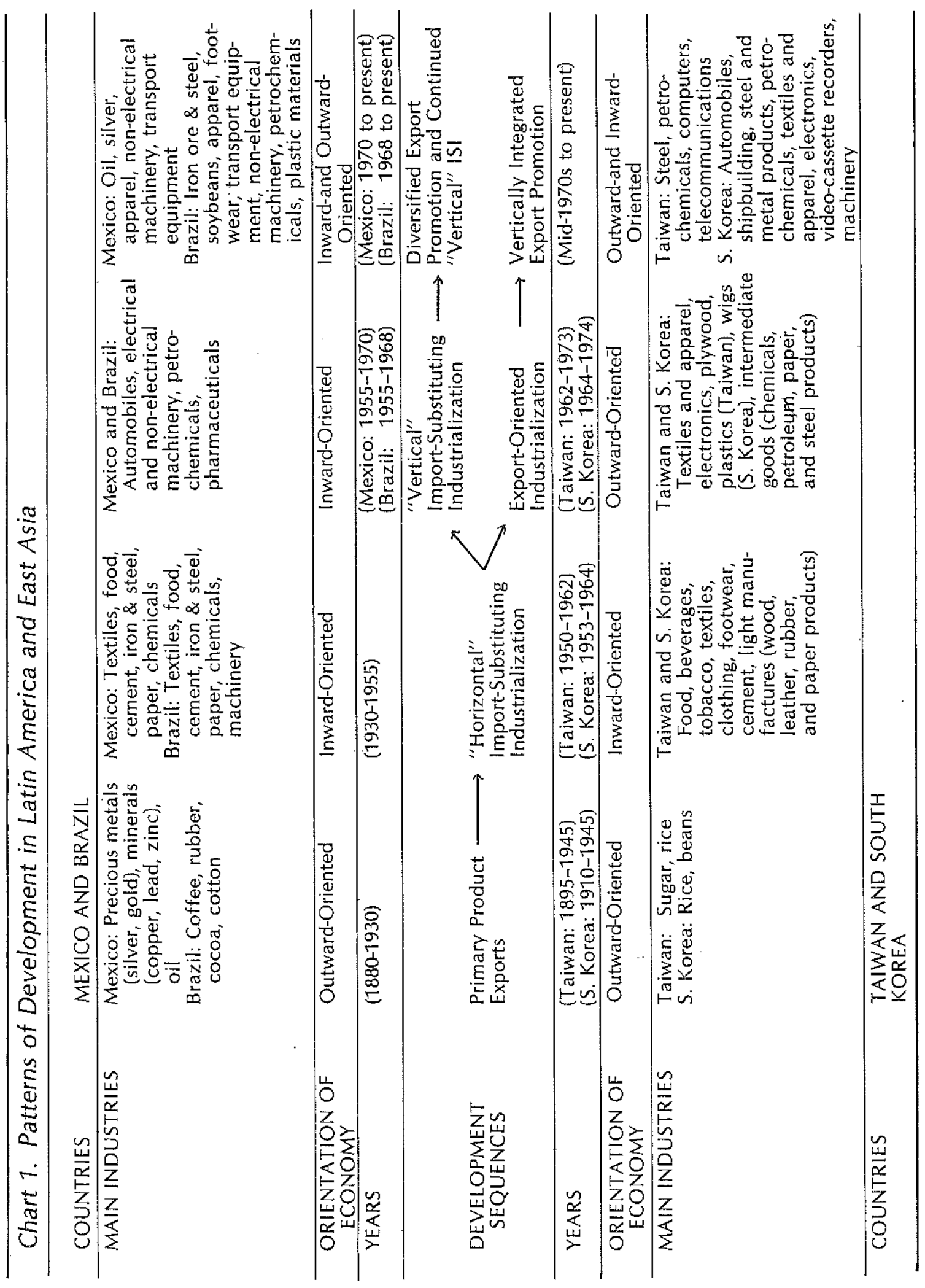


than on policy oscillations or shifts within specific ISI or EOI approaches.

We need to recognize, however, that if we define development strategies as relatively coherent sets of government policies that serve to relate a domestic economy to the global one, these strategies become a variable (rather than a constant) feature of national economic growth. In other words, government policies have not been of equal importance in each of the phases of economic development shown in Chart 1 . A careful examination of the leadership or followership role of government policies is a logical outgrowth of our framework, but it is not a task for this paper. Our working hypothesis would be that state-led industrialization becomes the norm in all four NICs following World War II, while in prior periods local government policies tend to have played a secondary role to the initiatives of foreign or domestic economic elites. In some instances, like the Japanese colonial era, the issue is moot because independent local governments did not even exist.

In the remainder of the paper, we will use the term "development strategies" for convenience to refer to the broad sequences outlined in Chart 1. However, one should bear in mind that there is an important analytical distinction between development "patterns" (which are economic outcomes) and the policies that make up government "strategies," which may or may not be instrumental in bringing about import-substituting or export-promoting industrial transformations.

\section{Timing and Sequence of Development Strategies}

Over time, each regional pair of NICs has followed a sequence that includes three development strategies that closely approximate ISI or EOI ideal types, plus a mixed strategy. An analysis of these sequences, as shown in Chart 1, suggests the following conclusions. First, the contrast often made between Latin America and East Asia as representing inward- and outward-oriented development strategies respectively is oversimplified. While this distinction is appropriate for some periods, a historical perspective shows that each of these regional pairs 
of NICs has pursued both inward- and outward-oriented approaches. ${ }^{16}$

Second, the first two development patterns that characterize the Latin American and East Asian NICs were based on primary product exports and horizontal ISI. The subsequent divergence in these regional sequences stems from the way in which they each responded to the common problems associated with the continuation of horizontal ISI; these problems included balance of payments pressures, rapidly rising inflation, high levels of dependence on intermediate and capital goods imports, and low levels of manufactured exports. ${ }^{17}$

Third, the timing and duration of these development patterns vary by region. Timing helps explain these sequences because the opportunities and constraints that shape development choices are constantly shifting. The East Asian NICs began to emphasize the export of manufactured products at a time of extraordinary dynamism in the world economy. The two decades that preceded the global economic crisis of the 1970's saw unprecedented annual growth rates of world industrial production (approximately 5.6 percent) and world trade (around 7.3 percent), relatively low inflation and high employment rates in the industrialized countries, and stable international monetary arrangements. ${ }^{18}$ The rate of growth of world trade was even higher between 1960 and 1973, when the average annual growth rate of exports reached almost 9 percent. Starting in 1973,

16. Indeed, a previous period of import-substitution may be a prerequisite for successful adoption of EOI based on national entrepreneurs. See Stephan Haggard and Tun-jen Cheng, "State Strategies, Local and Foreign Capital in the Gang of Four," in Frederic C. Deyo (ed.), The Political Economy of the New Asian Industrialism (Ithaca, N.Y.: Cornell University Press, 1987).

17. The problems associated with ISI in Latin America are dealt with by Werner Baer, "Import Substitution and Industrialization in Latin America: Experiences and Interpretations," Latin American Research Review 7:1 (Spring, 1972), pp. 95-122 and Albert O. Hirschman, "The Political Economy of Import-Substituting Industrialization in Latin America," The Quarterly Journal. of Economics, 82 (February, 1968), pp. 2-32. East Asian countries experienced similar problems with horizontal ISI. See, for example, Ching-yuan Lin, Industrialization in Taiwan, 1946-72: Trade and Import-Substitution Policies for Developing Countries (New York: Praeger Publishers, 1973), pp. 68-74.

18. W. W. Rostow, The World Economy: History and Prospect (Austin: University of Texas Press, 1978), p. 247. 
however, the global economy began to enter a troublesome phase. From 1973 to the end of the decade, the annual growth in world trade fell to 4.5 percent $^{19}$ as manufactured exports from the developing countries began to encounter stiffer protectionist measures in the industrialized markets.

Fourth, the development strategies of the Latin American and East Asian NICs appear to be converging, yet in reality they also are maintaining their distinctiveness. The large Latin American countries began to emphasize manufactured exports in the late 1960 's, primarily as a way to acquire enough foreign exchange to finance the imports necessary for furthering vertical ISI. One prominent economist has labeled this approach "exportadequate" to distinguish it from the East Asian "export-led" strategy. ${ }^{20}$ The East Asians, on the other hand, are developing vertically integrated industries in the consumer durable, intermediate, and capital goods sectors in order to enhance the flexibility and dynamism of their export-oriented approach, in which export volume is the key to national economic performance. These developments suggest that, over time, regardless of which of these two strategies a NIC is pursuing (EOI or advanced ISI), it is forced to incorporate elements of the other strategy in response to changing international circumstances and limitations within the strategies themselves.

\section{Determinants of Development Strategies}

Having provided a broad outline of the development patterns that characterize the Latin American and East Asian NICs, we now turn to a discussion of some of the key determinants of the strategies that make up these patterns. It is important to note, however, that this section of the paper is not intended to be definitive, but rather to suggest what we believe to be a fruitful

19. A. G. Kenwood and A. L. Lougheed, The Growth of the International Economy, 1820-1980 (London: George Allen \& Unwin, 1983), p. 299.

20. Albert Fishlow, "State and Economy in Latin America: New Models for the Current Economic paper presented at the Workshop on the Impact of Industrialized Nations, São Paulo, Bocial and Political Structure of the Newly 
research agenda. We raise, then, as many questions as we may answer. Future historical and statistical work undoubtedly will be required in examining the individual determinants we consider here, and in addition more detailed inquiry will be needed to look at how these diverse causal factors interact.

\section{Natural Resource Endowments and Internal Market Size}

When a particular development strategy is no longer viable, what factors influence a country's choice of its subsequent approach? In particular, why did Latin American countries respond to a crisis in horizontal ISI by adopting a vertical ISI strategy, while the East Asian countries responded to a similar crisis by adopting an export-oriented development strategy? Part of the answer is found in certain country specific characteristics, especially natural resource endowments and internal market size. Economists have long argued that foreign trade is much more important for small economies than for large ones. ${ }^{21}$ With few natural resources and relatively small markets, this argument goes, the East Asian countries had no choice but to pursue export-oriented industrialization. The Latin American countries, in contrast, are said to have had large enough potential markets, coupled with diverse export commodities (e.g., minerals, petroleum, agricultural goods), to have made vertical ISI feasible.

It would be foolish to argue that factors such as size of the internal market or natural resource endowments play no role whatsoever in the determination of national development strategies. Confinement to these factors alone, however, asserts an overly deterministic explanation for the outcomes of policy deliberations. The significance of policy choice is emphasized by the imperfect correlation between country size and protection in contemporary developing countries and by the fact that, as Balassa has pointed out, the East Asian NICs are not really small in market terms relative to many other developing coun-

21. Simon Kuznets, "Quantitative Aspects of the Economic Growth of Nations. IX. Level and Structure of Foreign Trade: Comparisons for Recent Years," Economic Development and Cultural Change 13, part 2 (October, 1964), pp. 1-106. 
tries. ${ }^{22}$ A cross-regional comparison of the causes and consequences of development strategies must consider choice as a real phenomenon to be explained. As such, the analysis must go beyond given structural features of these countries, such as resource endowments and internal market size, to consider factors such as geopolitical situation, linkages with the global economy, state structures, elite policy preferences, prevailing development ideologies, and social coalitions.

\section{Geopolitical Factors}

For purposes of this paper, we distinguish between two dimensions of the international system: the interstate system and the global economy. The former is discussed in terms of geopolitical factors, in particular the notion of contending regional hegemonies; the latter is analyzed in terms of four types of transnational economic linkages.

Hegemonic powers affect both the development patterns and strategies of countries within their sphere of influence in several ways. They channel goods and resources to, and extract them from, subordinate countries through political or military means, and/or through economic agents. Moreover, various mechanisms of control and the operation of market forces, together with the cooperation of local state elites, give dominant nations the opportunity to influence state and social structures, governmental policies, and prevailing ideologies in the subordinate states in ways favorable to the hegemon's interests. ${ }^{23}$

22. Balassa, "The Process of Industrial Development and. Alternative Development Strategies," pp. 2-3. In 1984. for example, South Korea's population of 40 million was larger than Argentina's 30 million. Brazil and Mexico, with populations of 133 million and 77 million respectively, are much larger than Korea or Taiwan (19 million), but the extensive poverty in these two Latin American countries reduces their effective market size for selected consumer goods to levels nearer those of the East Asian NICs than population figures alone would indicate. World Bank, World Development Report, 1986, Annex, Table 1, pp. 180-181.

23. Robert O. Keohane, After Hegemony: Cooperation and Discord in the World Political Economy (Princeton: Princeton University Press, 1984), pp. $32 \sim 46$. 
Latin America and East Asia each were subject to two clear periods of external domination, but the successive hegemonies for each region differed in their nature and timing. Latin America experienced British hegemony from the late nineteenth century to the beginning of World War I, and United States hegemony from the end of World War II to the present. In East Asia, Korea and Taiwan were subject to Japanese colonial rule from the late nineteenth century until the end of World War II. Following the defeat of the Japanese empire, the United States assumed a dominant role vis-à-vis newly independent South Korea and Taiwan. Since the early 1970's the predominance of the United States in South Korea and Taiwan has been challenged by the emergence of Japan as a global economic power. ${ }^{24}$

The two periods of external domination and influence that have obtained in East Asia each have significantly affected the nature of political, social, and economic development in South Korea and Taiwan. ${ }^{25}$ They help to account for the origins and nature of the "developmental state" in these two countries and for its degree of autonomy relative to their respective civil societies. The Japanese imperium, for example, left a legacy of strong state control. The relatively unscathed condition of the state bureaucracy at the end of the Second World War gave the state in the East Asian countries substantial autonomy relative to internal groups. U.S. hegemony contributed to this domestic autonomy as U.S. forces and polícies helped to weaken social groups that might have challenged the state, such as the

24. Giovanni Arrighi, "A Crisis of Hegemony," in Samir Amin et al. (eds.), Dynamics of Global Crisis (New York: Monthly Review Press, 1982), pp. 55-108; Robert O. Keohane, "Hegemonic Leadership and U.S. Foreign Economic Policy in the 'Long Decade' of the 1950s," in William P. Avery and David P. Rapkin (eds.), America in a Changing World Economy (New York: Longman, 1982), pp. 49-76.

25. For a discussion of the subsequent consequences of the Japanese colonial rule in Korea and Taiwan, see Bruce Cumings, "The Origins and Development of the Northeast Asian Political Economy: Industrial Sectors, Product Cycles, and Political Consequences," International Organization 38:1 (Winter, 1984), pp. 1-40. The economic aspects of colonialism for Taiwan and Korea respectively are treated in Samuel P. S. Ho, Economic Development of Taiwan, 1860-1970 (New Haven: Yale University Press, 1978), pp. 25-102 and Paul Kuznets, Economic Growth and Structure in the Republic of Korea (New Haven: Yale University Press, 1977), pp. 8-28. 
agrarian elite.

United States hegemony over Korea and Taiwan stimulated the adoption of liberal trade and investment policies in those two countries. Moreover, U.S. occupation forces in Korea contributed to the weakening of leftist influences within unions, of urban political parties, and of demands from the rural sector, at the same time as expropriated Japanese properties and U.S. aid provided substantial material resources to the state. ${ }^{26}$ Because U.S. hegemonic interests in East Asia and the ideological perspectives and policy preferences of the political elites often coincided, U.S. hegemony in that part of the world was cooperative rather than coercive regarding pursuit of an export-oriented development policy.

Development in Latin America, too, has been conditioned by the hegemonies that existed in the region. British hegemony, for example, reinforced the notion of free trade as applied to the export of primary products and the import of manufactured goods. ${ }^{27}$ The absence of any effective hegemony in Latin America during the 1930's was one of the reasons that the region was able to pursue independent political and economic experiments. ${ }^{28}$ Postwar United States hegemony has had a great deal to do with establishment of a favorable investment climate for multinational corporations in the region and with the high costs associated with Latin American commercial and financial diversification away from the United States. In contrast to the situation in East Asia, the policy preferences of domestic elites in Latin America clashed more seriously and more frequently with those of United States interests, so U.S. hegemony was more

26. Bruce Cumings, The Origins of the Korean War: Liberation and the Emergence of Seperate Regimes (Princeton: Princeton University Press, 1981). 27. On economic relations between Great Britain and Latin America see, for. example, D.C.M. Platt, Latin America and British Trade, 1806-1914 (London: Adams \& Black, 1972) and J. Fred Rippy, British Investments in Latin America, 1822-1949 (Minneapolis: University of Minnesota Press, 1959). A broad treatment of British influence in one Latin American country is Richard Graham's Britain and the Onset of Modernization in Brazil, 1850-1914 (Cambridge: Cambridge University Press, 1972).

28. These experiments are described in Rosemary Thorp (ed.), Latin America in the 1930s: The Role of the Periphery in World Crisis (New York: St. Martin's Press, 1984). 
likely to constrain than to facilitate the locally preferred development approach. ${ }^{29}$

\section{Transnational Economic Linkages}

Transnational economic linkages or TNELs (economic aid, export trade, direct foreign investment, and foreign loans) affect development strategies in several ways. First, they represent economic resources that may be used, singly or in diverse combinations and sequences, to finance development. Second, the extent to which one or more of these TNELs are available signifies opportunities that permit countries to pursue particular development strategies. Conversely, the absence of these resources constrains the choices of national policy makers. For example, large amounts of direct foreign investment facilitated vertical ISI in Latin America, much as the availability of foreign economic assistance facilitated horizontal ISI in East Asia. Third, the availability of these resources is conditioned by factors beyond as well as within the control of developing countries. Factors beyond the control of these countries include global economic conditions (e.g., trends in world trade, international capital markets, and the investment behavior of multinational corporations) and geopolitical pressures that help channel these resources toward some countries and away from others. National policies or conditions are factors within the control of developing countries that influence the extent to which one or more of these resources will be available to them.

Fourth, as Chart 2 shows, each of these TNELs has associated with it different institutional carriers or agents: Once present in a developing country, these actors become part of the constellation of interests that seek to influence policy choice. How this influence is expressed depends on regime type, social coalitions, and prevailing development ideologies. Finally, the destination

29. Several essays that explore the instruments and effects of U.S. hegemony in Latin America are contained in Julio Cotler and Richard R. Fagen (eds.), Latin America and the United States: The Changing Political Realities (Stanford: Stanford University Press, 1974). An excellent treatment of country experiences and regional themes is Tulio Halperin Donghi, Historia Contemporanea de América Latina (Madrid: Alianza Editorial, 1969). 
Determinants of Development Strategies / 21

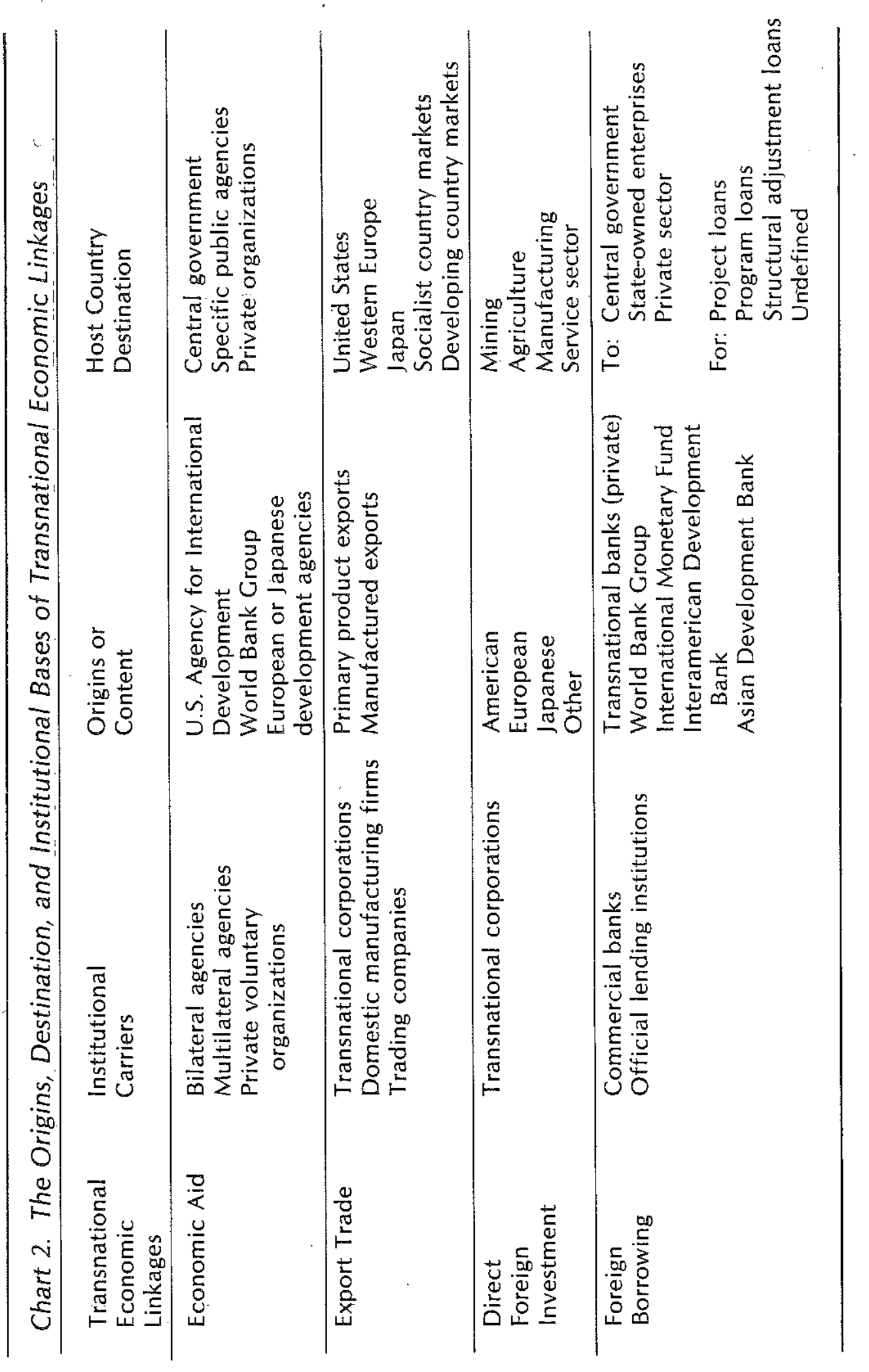




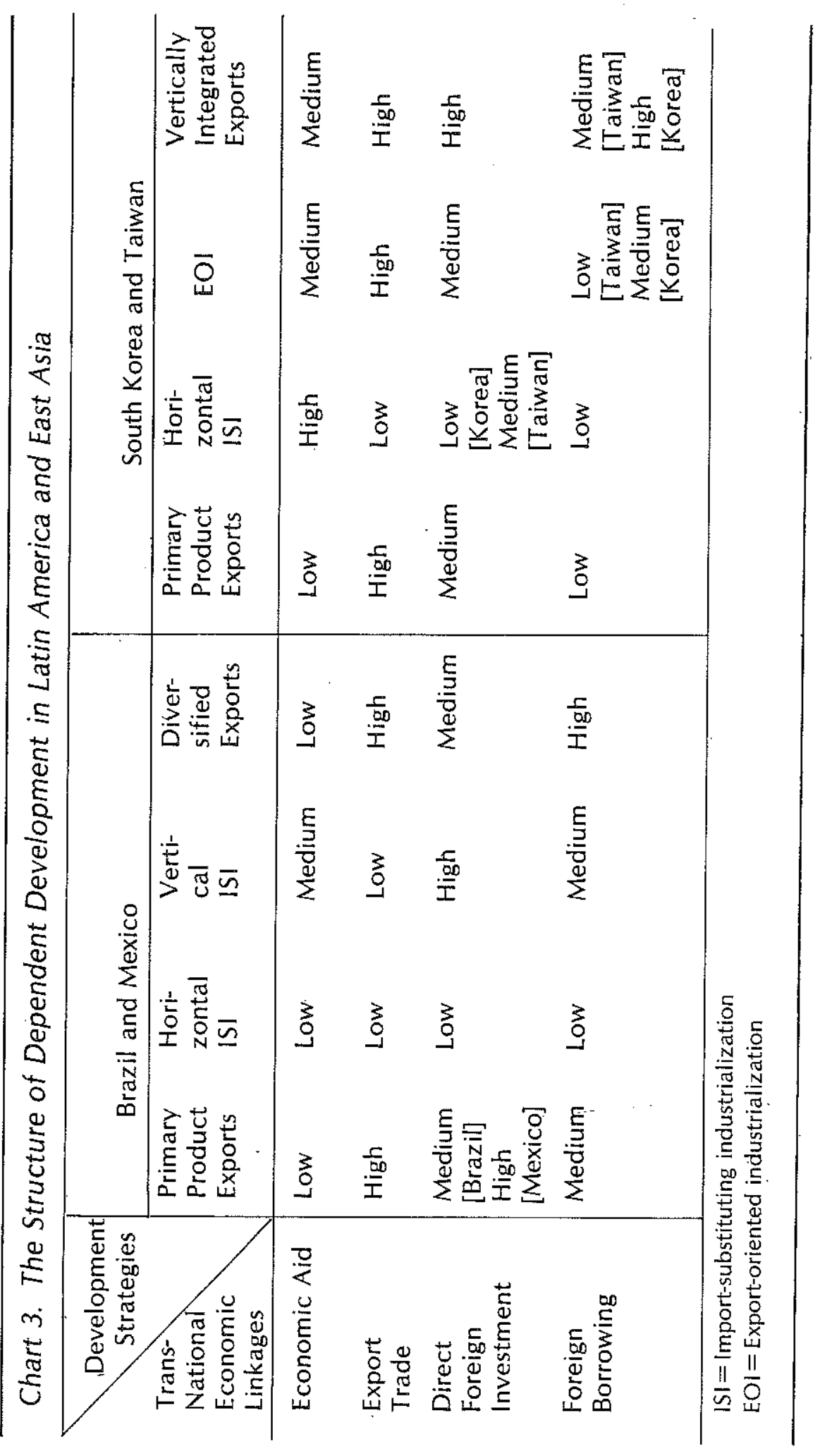


and use of these resources in a developing country affect development outcomes (depending on whether the resource is used productively or unproductively) as well as strategy choice (through its influence on the economic power of domestic actors). It matters, for example, whether these resources are used to finance fur coats and fine china or irrigation systems and highways, just as it matters whether the presence of these resources strengthens agrarian elites, urban middle classes, or the industrial working class.

Our analysis of TNELs across regions suggests the following conclusions, which derive from the relative weights assigned to these linkages in Chart 3. First, the salience of TNELs within each region varies markedly according to the strategy pursued. Said differently, each strategy is associated with a different mix of external resources used to finance development. Thus, for example, within Latin America the primary product export strategy required a great deal of export trade and only moderate amounts of direct foreign investment and foreign borrowing, whereas vertical ISI demanded little in the way of export trade but a great deal of external financing, primarily in the form of direct foreign investment. Similarly, in East Asia, horizontal ISI relied on lots of foreign aid and little in the way of export trade, whereas EOI was defined by extensive amounts of export trade and did not require the same degree of economic assistance from abroad.

Second, the salience of TNELs also varies within similar strategies across the two regions. For example, both regions went through a period of horizontal ISI, but the dynamics were different for the two regions. Import-substituting industrialization in Latin America came earlier than in East Asia, lasted longer, and was associated with populism; in Asia, labor and peasants were excluded from politics in the 1950's and had little direct influence over strategy choices. Moreover, the linkages through which each region related to the international economy while experiencing horizontal ISI were quite different. In East Asia, import substitution was financed primarily by massive amounts of foreign economic assistance, ${ }^{30}$ whereas in Latin America hori30. Ho, Economic Development of Taiwan, 1860-1970, pp. 110-111; Little, "Economic Reconnaissance," p. 457; Edward Mason et al., The Economic and 
zontal ISI tended to be financed largely by local industrialists with the support of the state and with limited participation by multinational corporations.

Third, the contrast with regard to TNELs is sharpest when we compare Latin America's vertical ISI with East Asia's EOI. The former relied primarily on foreign direct investments and external loans, but was oriented toward supplying local markets; the latter depended heavily on access to foreign markets, but was carried out largely by domestic entrepreneurs who drew heavily on local financial resources.

Fourth, a closer look at the evolution of each TNEL also highlights major differences between the two regions. Historically direct foreign investment and foreign loans have represented the most important external economic resources for the Latin American NICs; in contrast, export trade and foreign economic assistance have been the key forms of East Asian linkage to the international economy. Finally, we should not overlook a fundamental similarity between the two regions. The NICs in both Latin America and East Asia have extensively utilized linkages with the international economy in their industrialization efforts. To put this in another way, none of these countries has been able to avoid heavy reliance on one or more of the four TNELs we have identified.

\section{State Structures and Policy Preferences}

Development strategies are state-centered policies-i.e., they are policies designed and executed in large part by governments. Different groups in society may have strong policy preferences on certain issues, but the formulation of a development strategy implies at least some degree of state leadership. Since the state is the agent that formulates a development strategy, an interest in the sequence and choice of these strategies requires us to examine the ways in which political structures buffer the state from the pressures of civil society, as well as the content of the policy preferences of governmental elites.

Social Modernization of the Republic of Korea (Cambridge, Ma.: Council on East Asian Studies, Harvard University, 1980), p. 181 and footnote 19. 
A standard reference point for current research on the nature of the state and its role in development has been Guillermo O'Donnell's analysis of the emergence and dynamics of "bureaucratic-authoritarian" (BA) regimes in the southern cone of Latin America. ${ }^{31}$ More recently, Bruce Cumings introduced the term "bureaucratic-authoritarian industrializing regimes" (BAIRs) to refer to the strong states in Taiwan and South Korea. ${ }^{32}$ It seems useful for researchers of both Latin America and East Asia to push toward some integrating or overarching conceptualization of the state in the context of late, dependent, capitalist development. In both regions, the negative effects of authoritarianism in areas such as the suppression of human rights is putatively counterbalanced by extensive, rapid economic growth. The coexistence of authoritarianism and capitalism appears to be taken for granted in this setting.

The similarities among the states in the newly industrializing countries of the two regions are quite apparent: they tend to be strong, centralized, authoritarian (often under military control), and actively and extensively involved in economic affairs. ${ }^{33}$ The differences are equally notable. The origins of the BA regimes and the BAIRs contrast sharply. Exclusionary BA regimes in Latin American (this includes Brazil, Argentina, Uruguay, and Chile, but not Mexico) emerged from the crises produced by periods of populist rule, when organized labor had been one of the important bases of social support of the state. BAIRs, on the other hand, inherited the centralized state apparatus from the Japanese colonial period and enjoyed a significant measure of autonomy from local social groups and classes, including those most likely to be affected by rapid industrialization, such as large landowners and workers. Whereas BA regimes had to repress previously mobilized popular sector organizations, such

31. Guillermo O'Donnell, Modernization and Bureaucratic-Authoritarianism: Studies in South American Politics (Berkeley: Institute of International Studies, University of California, 1973).

32. Cumings, "The Origins and Development of the Northeast Asian Political Economy."

33. For the East Asian NICs the economic role of the state is analyzed in several essays in Robert Wade and Cordon White (eds.), Developmental States in East Asia: Capitalist and Socialist, IDS Bulletin 15:2 (1984). 
as free trade unions, the BAIRs did not confront an activated popular sector and were exclusionary from the outset.

A second difference relates to the role of the military. Although the military is prominent in both BA regimes and BAIRs, in the Latin American context the nature of the threat to which the military is responding is largely internal insurgency, while in South Korea and Taiwan the possibility of external invasion from neighboring communist countries is real and alarming. ${ }^{34}$ Thus, even though the military penetrates far more deeply into civil society in East Asia than in Latin America, it may be that at some level the military is granted a greater degree of legitimacy in South Korea and Taiwan than in the BA regimes because of national security considerations.

A third contrast has to do with the social alliances on which the two kinds of regimes are based. In most Latin American BA regimes, international capital is an important part of the dominant coalition that also includes the military, select industrial groups, and civilian technocrats. In the East Asian BAIRs, international capital is a relatively minor actor, while the role of domestic economic groups integrated across industrial, trade, and financial sectors is central. Although labor is excluded in both $\mathrm{BA}$ regimes and BAIRs, labor appears to be a potentially more influential actor in Latin America than in East Asia. ${ }^{35}$

If we are to fruitfully compare and contrast the nature and role of interventionist states in a cross-regional setting, we need to go beyond relatively simplistic notions like "strong" versus "weak" states. For example, both the Brazilian and South Korean states over the past two decades can be characterized as "strong" since they have been led by military factions with an

34. Since 1949, Taiwan has supported on a per capita basis one of the world's largest armies (estimated to be between 500,000 and 600,000 men), far larger than the military force that would be necessary to maintain internal political order. Ho, Economic Development of Taiwan, 1860-1970, pp. 107-108.

35. Labor in the East Asian cases, with comparative reference to Latin America, is the subject of Frederic C. Deyo, "Industrialization and the Structuring of Asian Labor Movements: The 'Gang of Four'," in Michael Hanagan and Charles Stephenson (eds.), Confrontation, Class Consciousness, and the Labor Process: Studies in Proletarian Class Formation (Westport, Ct.: Greenwood Press, 1986), and "State Labor Regimes and the New Asian Industrialism," in Deyo (ed.), The Political Economy of the New Asian Industrialism. 
authoritarian, centralized approach to economic decisionmaking and considerable insulation from societal pressures. Korea's export-led economic success, two observers have argued, was dependent upon the change from the "soft" state under Rhee, whose administration was ineffectual in enforcing economic regulations, to the "hard" state under Park. The liberalization of economic policies, in this view, required a government that was able to impose compulsory bureaucratic obligations and to direct bureaucratic discretion towards what it identified as economically desirable ends. ${ }^{36}$

The similarities notwithstanding, the Brazilian and Korean regimes also show some notable differences. By the late 1970's, around 600 Brazilian public enterprises existed in a wide variety of economic activities, with the public sector in Brazil accounting for over 40 percent of gross capital formation since the 1940 's. South Korea, in contrast, has far fewer public enterprises in a relatively narrow range of industries, with the state sector representing less than 13 percent of total gross national product. Furthermore, the military has permeated society and perhaps legitimated itself to a much greater degree in South Korea than in Brazil (probably reflecting the overt military threat to national security represented by the North Korean forces above the 38th parallel), while the Brazilian state has been more vulnerable to organized societal pressures and democratic overtures than its South Korean counterpart. Similar kinds of parallels and differences emerge from a comparison of Mexico and Taiwan.

State-led industrialization in the NICs, with the exception of limited democratic interludes, has been characterized by authoritarianism. Yet authoritarianism per se does not guarantee either state strength or state autonomy. The majority of developing countries have authoritarian regimes, but few have autonomous or strong states. (The reverse case of a strong state and a nonauthoritarian regime is postwar Japan.) Politica! leadership, economic ideology, the role of the techno-

36. Leroy $\mathrm{P}$ Jones and II Sakong, Government, Business, and Enterpreneurship in Economic Development: The Korean Case. Studies in the Modernization of the Republic of Korea: 1945-1975 (Cambridge, Ma.: Council on East Asian Studies, Harvard University, 1980), p. 296. 
bureaucracy, and the organizational resources and discretion of decentralized public agencies all need to be taken into consideration to show how state intervention has come about and been made effective in specific historical contexts. One promising approach would be to compare interventionist states in terms of the various economic roles they perform; these include their extractive capacities (e.g., collecting tax revenues), allocative capacities (e.g., distributing credit), planning distributing-credit), planning (e.g., targeting industries domestically and internationally), facilitative capacities (e.g., providing infrastructures), and productive capacities (e.g., owning firms and producing goods). According to these criteria, Latin American NICs like Brazil and Mexico have emphasized direct productive activities, while state strength in the East Asian NICs is rooted more in their allocative and planning capacities.

An examination of the policy preferences of state elites also directs attention to prevailing development ideologies. In Latin America, for example, the region's experience with the economic problems of the 1930's cleared the way for generalized acceptance of the development strategy espoused by the United Nations' Economic Commission for Latin America (ECLA). Under the intellectual guidance of Raúl Prebisch, ECLA had begun to argue by 1950 that Latin American nations should pursue the path of increased local industrialization, despite the injunction of neoclassical economists who urged that the principal engine of growth ought to be a renewed emphasis on primary product exports. ${ }^{37}$ In the East Asian NICs, the adoption of an exportoriented development strategy was encouraged by the U.S. economic missions that accompanied the massive amount of American assistance. An analysis of the sources (including the international transmission) of policy-relevant ideas and development ideologies is a subject that is deserving of much more detailed analysis.

37. Albert O. Hirschman, "Ideologies of Economic Development in Latin America," in Albert Hirschman (ed.), Latin American Issues: Essays and Comments (New York: The Twentieth Century Fund, 1961), pp. 12-23. 


\section{Social Coalitions}

The development experiences of the Latin American and East Asian NICs are affected by social coalitions - i.e., constellations of interests that support or oppose particular development strategies. For example, traditional agrarian and mining export elites tended to support and were favored by the primary product export model, while local manufacturing firms and urban labor generally opposed and were adversely affected by that experience. Conversely, industrial workers, national producers of finished consumer goods, and middle- and lower-income consumers were often united in their support of horizontal import substitution, even as the agro-export elite opposed this approach which jeopardized their privileged position.

As the initial industrialization phase ends, however, the political parameters of continuing industrial expansion begin to narrow. ${ }^{38}$ For countries like Argentina, Brazil, and Mexico, which promoted investment in consumer durable as well as intermediate goods sectors (vertical ISI), the social basis of this strategy was the so-called "triple alliance" of multinational corporations, affiliated local manufacturers, and the state, along with skilled workers and upper-middle class consumers who can afford to buy items like automobiles and major electrical applances. ${ }^{39}$ Agro-export elites, non-import-substituting firms, and the poor had little to gain from this strategy, although the political climate was such that they did not effectively challenge it. Finally, industrial export promotion both in the East Asian NICs and subsequently in the large Latin American nations favored producers (both domestic and foreign) of exportable manufactured products, while disfavoring traditional export companies, import-substituting firms, and organized labor.

This sketch of the principal social groupings associated with

38. For a discussion of this process as it has occurred in Latin America, see Robert R. Kaufman, "Industrial Change and Authoritarian Rule in Latin America: A Concrete Review of the Bureaucratic-Authoritarian Model," in David Collier (ed.), The New Authoritarianism in Latin America (Princeton: Princeton University Press, 1979), pp. 165-253.

39. This alliance is detailed for the case of Brazil in Peter Evans, Dependent Development: The Alliance of Multinational, State, and Local Capital in Brazil (Princeton: Princeton University Press, 1979). 
each strategy is largely a post hoc reconstruction of loosely knit social coalitions or alliances. That is, these are the groups that provided the social bases of support for a strategy once it had become stabilized. It is more difficult, yet equally important, to determine the social forces that make possible the transition from one development strategy to another (what Guillermo O'Donnell calls, for some phases of the Latin American experience, "coup coalitions").

These shifting constellations of interests are not likely to be the same across regions, nor are the forces that contribute to the downfall of one strategy necessarily those that initiate or help institutionalize a subsequent strategy. The analysis of social coalitions, therefore, must be flexible enough to account for both periods of stability as well as turning points in the development process. In Brazil, for example, the "triple alliance" that consolidated the industrial deepening of vertical ISI was narrower than the "coup coalition" that brought an end to the populist policies of Coulart in the mid-1960's, yet it was also broader than the "coalitional duo" of multinational corporations and the state that held sway at the beginning of the 1970's when the repressiveness and the technocratic orientation of the military government led to the erosion of some of the Brazilian regime's earlier support. ${ }^{40}$ Similarly, the importance of external capital (aid, direct investment, and loans), overseas markets, or the influence of foreign advisors has fluctuated dramatically visà-vis domestic counterparts in East Asia depending on whether the subject is maintenance or change of a given development strategy.

\section{Conclusions}

This paper has traced the alternative sequences of development strategies in Latin America and East Asia and analyzed the determinants of those contrasting sequences. The NICs of Latin

40. Guillermo O'Donnell, "Reflections on the Patterns of Change in the Bureaucratic-Authoritarian State," Latin American Research Review 13:1 (1978), pp. 3-38. 
America and East Asia have differed markedly in terms of strategy choices. Most noticeably, the Latin American NICs chose to pursue vertical ISI and the East Asian NICs chose to pursue EOI when each of them found that they could no longer rely on horizontal ISI as the primary stimulus to economic growth. Their choices differed despite the similarity in the nature of the crisis that made continued adoption of horizontal ISI unfeasible.

The cross-regional comparison has permitted us to deal with the role of external and internal factors in the determination of national policies and with the interplay between transnational economic linkages and domestic arrangements. The linkages through which the NICs of Latin America and East Asia have effected their respective interactions with the global economy have varied by region. The heavy reliance of East Asian nations on foreign aid from the United States in the 1950's and early $1960^{\prime} \mathrm{s}$ and the major emphasis placed on manufactured export items since the mid-1960's contrasts sharply with the experience of the large Latin American countries, which have relied on primary product exports, direct foreign investment by transnational corporations, and since the 1970's spiraling foreign loans. These contrasting constellations of linkages, with their differences in origins, destinations, and institutional carriers associated with each particular linkage, help us account for the heterogeneity of organizational interests that mediate between these linkages and national development outcomes.

Although we have limited ourselves to focusing on four countries in this paper, there are other very interesting cases that raise related development issues. For example, the ongoing experiment of the People's Republic of China with specialized export processing zones introduces the possibility that the world's most populous nation may begin to compete directly with its Asian neighbors in low-cost, high value-added export activities. ${ }^{41}$ The Philippines, on the other hand, is a case of an East Asian nation which, for various reasons, has thus far failed in its

41. Xiangming Chen, "China's Special Economic Zones: Origins and Initial Consequences of a New Development Strategy," in Gereffi (ed.), The Origins and Consequences of National Development Strategies. 
efforts to successfully adopt an export-oriented strategy leading to industrialization. ${ }^{42}$ Finally, the so-called "second tier" countries or emerging NICs, such as Colombia, Malaysia, or Thailand, are perhaps on the verge of becoming sufficiently industrialized to qualify for NIC status themselves. ${ }^{43}$ They raise the issue of whether the path by which the NICs achieved their relatively high levels of economic development is replicable given the interplay of domestic and international factors that is conditioning development in these second-tier countries.

The implications of the foregoing analysis for development in the two regions are the following. Industrialization was greatly accelerated in the East Asian NICs through massive amounts of U.S. foreign economic assistance which facilitated the development of a domestic entrepreneurial class, the avoidance of foreign exchange bottlenecks, and the maintenance of political stability. Industrialization in East Asia also has depended upon the production of manufactured goods for foreign markets. This linkage to the international economy made these NICs vulnerable to global recession and to protectionism in the industrialized markets where they sold most of their goods. On the other hand, this linkage created an imperative for flexibility in state policy and entrepreneurial behavior that proved important when global economic circumstances turned adverse.

In the Latin American NICs, vertically integrated industrialization was financed during the 1950's and 1960's in substantial measure by direct foreign investment, and in the 1970's by foreign loans. This situation had several consequences for these NICs. It stymied the development of a domestic bourgeoisie;

42. Walden Bello, David Kinley, and Elaine Elinson, Development Debacle: The World Bank in the Philippines (San Francisco: Institute for Food and Development Policy, 1982); Robert T. Snow. "The Bourgeois Opposition to Export-Oriented Industrialization in the Philippines," unpublished paper (October, 1983).

43. "Developing Country Exports of Manufactured Products: The Experience of the 'Second-Tier' Countries," in Development Co-operation: Efforts and Policies of the Members of the Development Assistance Committee (Paris: Organization for Economic Co-operation and Development, November, 1982), p. 123; Roy Hofheinz, Jr. and Kent E. Calder, The Eastasia Edge (New York: Basic Books, 1982); John Wong, "Export-Oriented Industrialization in Asia: Pattern and Process," unpublished paper, National University of Singapore (October, 1983). 
weakened the control of national decision makers over the most dynamic sectors of their economies, and gave significant influence over national macroeconomic policies to external actors (such as the International Monetary Fund). In consequence, it helped reduce the effectiveness with which these countries have been able to adapt to changing international economic circumstances.

The explanation of strategy choice in developing countries frequently gives primacy to the international political economy. However, since the NICs of the two regions experienced their crises of horizontal ISI at approximately the same time (i.e., the mid-1950's to early 1960's), and so faced roughly similar global economic environments, external factors alone cannot explain the variation in subsequent strategies. Analysis must consider the interplay between linkages with the world economy and domestic political arrangements. In addition, we have found it important to make explicit the entire set of external linkages through which these four countries relate to international forces in order to identify the factors that condition development options, policies, and outcomes. In this view, particular external linkages are not presumed necessarily to have either positive or negative effects on the development process. The regional contrast makes especially clear that external linkages may be opportunities and not just constraints for developing countries. 